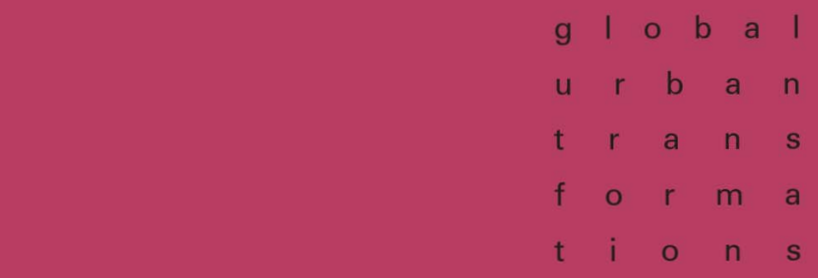

urban

transformations
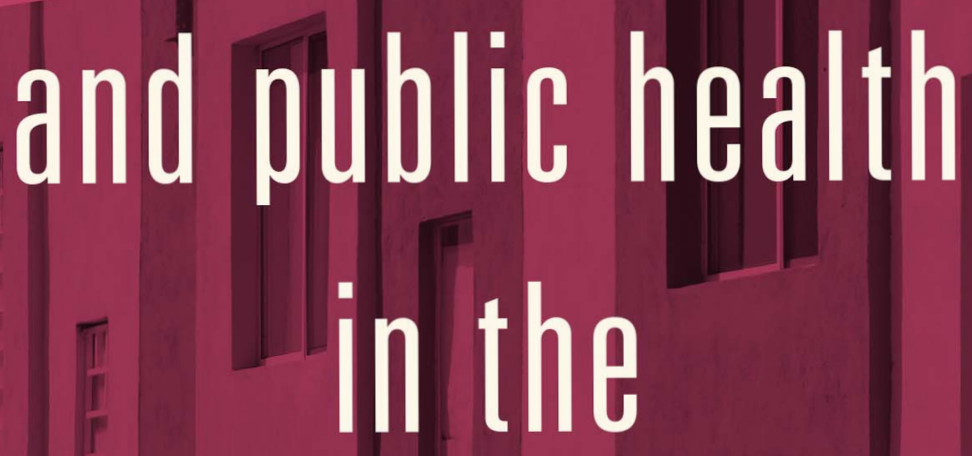

emergent eity

edited by michael keith and

andreza aruska de souza santos 


\section{Urban transformations and public health in the emergent city}

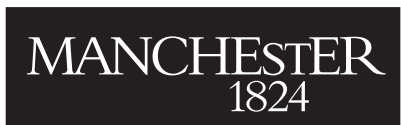

Manchester University Press 


$$
\begin{array}{cccccc}
g & \text { l } & o & b & a & \text { l } \\
u & r & b & a & n \\
t & r & a & n & s \\
f & o & r & m & a \\
t & i & o & n & s
\end{array}
$$

Series Editors

Michael Keith and Susan Parnell 


\section{Urban transformations and public health in the emergent city}

Edited by Michael Keith and Andreza

Aruska de Souza Santos

Manchester University Press 
While copyright in the volume as a whole is vested in Manchester University Press, copyright in individual chapters belongs to their respective authors.

This electronic version has been made freely available under a Creative Commons (CC-BY-NC-ND) licence, which permits non-commercial use, distribution and reproduction provided the editors, chapter authors and Manchester University Press are fully cited and no modifications or adaptations are made. Details of the licence can be viewed at https://creativecommons.org/licenses/by-nc-nd/4.0/

Published by Manchester University Press

Altrincham Street, Manchester M1 7JA

www.manchesteruniversitypress.co.uk

British Library Cataloguing-in-Publication Data

A catalogue record for this book is available from the British Library

ISBN 9781526150950 hardback

ISBN 9781526150943 open access

First published 2020

The publisher has no responsibility for the persistence or accuracy of URLs for any external or third-party internet websites referred to in this book, and does not guarantee that any content on such websites is, or will remain, accurate or appropriate.

Cover design: Daniel Benneworth-Gray

Typeset by

Servis Filmsetting Ltd, Stockport, Cheshire 